\title{
EVALUASI PENGARUH TEKNOLOGI, PENGGUNA DAN ORGANISASI TERHADAP MANFAAT DARI PENERAPAN E-PROCUREMENT
}

\author{
${ }^{1}$ I Gusti Ayu Agung Mas Aristamy, ${ }^{2}$ Theresia Hendrawati \\ ${ }^{1,2}$ Prodi Teknik Informatika, STMIK STIKOM Indonesia, \\ Jalan Tukad Pakerisan No.97 Panjer, Denpasar, Bali. \\ Email:19aungmas.aristamy@stiki-indonesia.ac.id, ${ }^{2}$ theresia.hendrawati@stiki-indonesia.ac.id
}

(Diterima:15 Desember 2019,direvisi:5 Mei 2020, disetujui:6 Mei 2020 )

\begin{abstract}
The government is trying to realize an open and democratic government by improving and optimizing public services through the establishment of electronic procurement of goods/services. The purpose of the establishment of E-procurement is to realize the procurement of government goods/services that is effective, efficient, transparent, fair, non-discriminatory, and accountable. However, there are still many obstacles found in the implementation of E-procurement. This research aims to evaluate the Eprocurement system which takes a case study on the E-procurement of the Provincial Government of Bali. An evaluation is conducted to find out the factors that support and hinder the implementation of the E-Procurement system in the Provincial Government of Bali. The system evaluation method chosen for this research is the HOT-Fit method. This method was chosen because it covers aspects of Human, Organization, and Technology. The results of this study state that the factors Technology, Human and Organizations have a positive and significant influence on the implementation of the EProcurement system, so that system users feel the benefits provided by the E-Procurement system. The inhibiting factor so far is that; there are still several stages in the process of procurement of goods and services that are still manual or have not been fully implemented by the system.
\end{abstract}

Keywords: Information System Evaluation, E-Procurement, HOT-Fit.

\begin{abstract}
ABSTRAK
Pemerintah tengah berupaya mewujudkan pemerintahan yang terbuka dan demokratis dengan cara meningkatkan dan mengoptimalkan layanan publik melalui dibentuknya E-procurement atau pengadaan barang/jasa berbasis elektronik. Tujuan dari dibentuknya E-procurement adalah untuk mewujudkan pengadaan barang/jasa pemerintah yang efektif, efisien, transparan, adil, tidak diskriminatif dan akuntabel. Namun, dalam penerapannya masih banyak kendala yang ditemukan pada penerapan E-procurement. Melihat dari banyaknya kendala yang ditemui, penelitian ini bertujuan untuk melakukan evaluasi sistem E-procurement yang mengambil studi kasus pada $E$ procurement milik Pemerintah Provinsi Bali. Evaluasi dilakukan untuk mengetahui faktor yang menjadi pendukung serta penghambat dari penerapan sistem E-Procurement di Pemerintah Provinsi Bali. Metode evaluasi sistem yang dipilih untuk penelitian ini adalah metode HOT-Fit. Metode ini dipilih karena mencakup aspek Human (Pengguna), Organization (Instansi/Organisasi) dan Technology (Teknologi/Sistem). Hasil dari penelitian ini menyatakan bahwa faktor Teknologi, Pengguna dan Organisasi memiliki pengaruh yang positif dan signifikan terhadap penerapan sistem EProcurement, sehingga pengguna sistem merasakan manfaat yang diberikan oleh adanya sistem EProcurement. Faktor yang menjadi penghambat sejauh ini adalah masih adanya beberapa tahapan dalam proses pengadaan barang dan jasa yang masih manual atau belum sepenuhnya dilaksanakan by sistem.
\end{abstract}

Kata Kunci: Evaluasi Sistem Informasi, E-procurement, HOT-Fit.

\section{PENDAHULUAN}

Pengadaan barang dan jasa merupakan salah satu kegiatan pemerintah yang penyelenggaraannya harus diupayakan secara efektif, efisien dan transparan sesuai dengan Peraturan Presiden Nomor 54 Tahun 2010 dan Perubahannya Pasal 1 ayat (1) dalam rangka mewujudkan tata kelola pemerintahan yang baik (good governance). Pemerintah tengah berupaya mewujudkan pemerintahan yang terbuka 
dan demokratis dengan cara meningkatkan dan mengoptimalkan layanan publik melalui dibentuknya E-procurement atau pengadaan barang/jasa berbasis elektronik. E-procurement adalah digitalisasi dari kegiatan pembelian, seperti pencarian, pemilihan, komunikasi, penawaran atau pemberian kontrak [1]. Tujuan dari dibentuknya E-procurement adalah untuk mewujudkan pengadaan barang/jasa pemerintah yang efektif, efisien, transparan, adil, tidak diskriminatif dan akuntabel. Transaparan yang dimaksud adalah sistem memiliki peraturan dan prosedur yang jelas, dokumen tender yang terstandarisasi, kontrak tender yang terstandarisasi dan proses yang adil. Transparansi total diwajibkan ada sehubungan dengan keputusan pengadaan. Semua penghargaan harus diberitahukan secara resmi kepada rekanan penawar yang berhasil dan kemudian ditampilkan secara publik di papan pengumuman atau situs web pengadaan [2]. Berdasarkan kelebihan yang dimiliki oleh $E$ procurement, maka Komisi Pemberantasan Korupsi (KPK) mendorong seluruh instansi pemerintahan untuk menerapkan E-procurement dalam sistem pengadaan barang dan jasanya, karena implementasi E-procurement dianggap mampu menghemat anggaran dan waktu yang digunakan dalam proses pengadaan serta meningkatkan transparansi dan kompetisi dalam pelaksanaan pengadaan barang/jasa pemerintah.

Mengacu pada penelitian [3], yang mengutip Sutedi, E-Procurement merupakan sebuah sistem yang digunakan dalam kegiatan lelang pengadaan barang dan jasa oleh pemerintah dengan memanfaatkan kemajuan teknologi informasi berbasis internet. Dengan memanfaatkan kemajuan teknologi informasi ini diharapkan E-Procurement dapat membuat kegiatan pengadaan barang dan jasa pemerintah berlangsung secara efektif, efisien, terbuka dan akuntabel. Pengertian lainnya oleh Andrianto, mengatakan bahwa E-Procurement adalah proses pengadaan barang dan jasa yang dilakukan melalui lelang secara elektronik. Pengadaan barang dan jasa secara elektronik merupakan ini juga menjadi salah satu mekanisme dalam mewujudkan nilai-nilai good governance yang harus diterapkan oleh instansi pemerintahan di Indonesia.

Pada penelitian yang dilakukan oleh [4], dikatakan bahwa Provinsi Jawa Barat merupakan salah satu contoh provinsi yang berhasil menerapkan sistem E-Procurement. Hal ini dibuktikan dengan adanya penghematan anggaran sekitar Rp. 383 milyar untuk kategori lelang barang dan jasa pada tahun 2015. Meskipun menunjukkan hasil yang dapat dikatakan berhasil, namun pada kenyataannya jumlah korupsi dalam hal pengadaan barang dan jasa masih tetap tinggi. Kasus korupsi pengadaan barang dan jasa masih merupakan kasus korupsi yang banyak ditangani oleh KPK. Statistik pada Anti-Corruption Clearing House (ACCH) menunjukkan kasus korupsi dalam hal pengadaan barang dan jasa terus mengalami peningkatan mulai dari tahun 2015 sampai 2018 dengan total kasus sebanyak 188 kasus [5]. Statistik ini menunjukkan bahwa penerapan E-Procurement ternyata belum sepenuhnya mencegah terjadinya korupsi, kolusi, dan nepotisme dalam pengadaan barang dan jasa pemerintah [6].

Pada penelitian yang dilakukan oleh [7], dipaparkan mengenai kendala-kendala apa saja yang menjadi permasalahan pada penerapan E-procurement. Adapun kendala-kendala tersebut diantaranya tidak adanya keyakinan atas kelegalan hukum pada E-procurement, budaya perusahaan yang tidak mendukung, dukungan top manajemen yang minim, infrastruktur teknis yang tidak memadai, sistem TI yang terlalu mahal, kurangnya pengetahuan personil akan E-procurement, keamanan transaksi yang masih minim, dan tidak ada manfaat bisnis yang dicapai. Sedangkan, menurut Sulaiman dan Chen yang dikutip pada penelitian [8], kendala pada pelaksanaan E-procurement di Indonesia dibagi menjadi 4, yaitu dalam bidang hukum, infrastruktur, standarisasi prosedur, serta kontrol proses pengadaan E-procurement yang menyebabkan pengguna tidak merasakan manfaat dari adanya Eprocurement. Penelitian lainnya oleh Mohd Nasrun Mohd Nawi et.al.[9], telah mengidentifikasi faktor-faktor tertentu yang berkontribusi terhadap tantangan dalam implementasi E-procurement pada studi literatur. Adapun faktor-faktor tersebut seperti teknologi, infrastruktur dan perundang-undangan, lingkungan; selain kendala sumber daya dan karakteristik organisasi dan manajemen. Sistem Pengadaan Elektronik merupakan pengembangan yang relatif baru di bidang aplikasi bisnis. Masih kurangnya model referensi yang dapat diperbandingkan terutama di institusi yang baru mulai mempelajari fungsionalitas dan penggunaan sistem ini di organisasi mereka juga menjadi kendala yang cukup berdampak pada penerapan E-procurement.

Melihat dari banyaknya kendala yang ditemui, dapat dikatakan bahwa penerapan E-Procurement di Indonesia hingga 2017 masih belum optimal. Berdasarkan permasalahan tersebut, perlu dilakukan evaluasi sistem E-procurement untuk mengetahui faktor-faktor yang menjadi pendukung dan kendala 
dari penerapan E-Procurement. Evaluasi pada penelitian ini mengambil studi kasus pada Sistem Pengadaan Secara Elektronik (SPSE) atau yang biasa disebut dengan E-Procurement. E-Procurement Pemerintah Provinsi Bali mulai aktif beroperasi pada tahun 2010. Hingga saat ini, E-Procurement sudah beroperasi selama 9 tahun, yang mana artinya sistem ini sudah layak untuk di evaluasi. Mengingat evaluasi suatu sistem bias dilakukan jika sistem sudah terimplementasi selama lebih dari 3 tahun. Metode yang digunakan untuk mengevaluasi sistem E-procurement harus mencakup aspekaspek yang berperan dalam implementasi E-procurement itu sendiri. Pada SPSE Pemerintah Provinsi Bali, aspek-aspek yang berperan adalah Teknologi Informasi, Pengguna, dan Instansi Pemerintahan, yang mana semua aspek tersebut terdapat pada model evaluasi HOT Fit. HOT Fit adalah suatu model evaluasi sistem informasi yang diperkenalkan oleh Yusof [10].

Manajemen pada tahun 1990-an (MIT90s), memperkenalkan sebuah framework yang terkenal yaitu IT-Organization Fit Model. Framework ini menjelaskan mengenai keberhasilan teknologi informasi dalam organisasi bergantung kepada keseimbangan dari faktor-faktor yaitu lingkungan eksternal, strategi organisasi, strategi bisnis, struktur organisasi, proses manajemen, teknologi, peran dan keterampilan. Teknologi diharapkan dapat mempengaruhi proses manajemen, sehingga mampu memberikan dampak kepada kinerja organisasi [11]. Pada akhirnya, sebuah framework yang mengkombinasikan konsep antara D\&M IS Success Model dan IT-Organizational Fit dibangun dan disebut Human-Organization-Technology (HOT) Fit Model. Model HOT Fit dapat dilihat pada Gambar 1 berikut

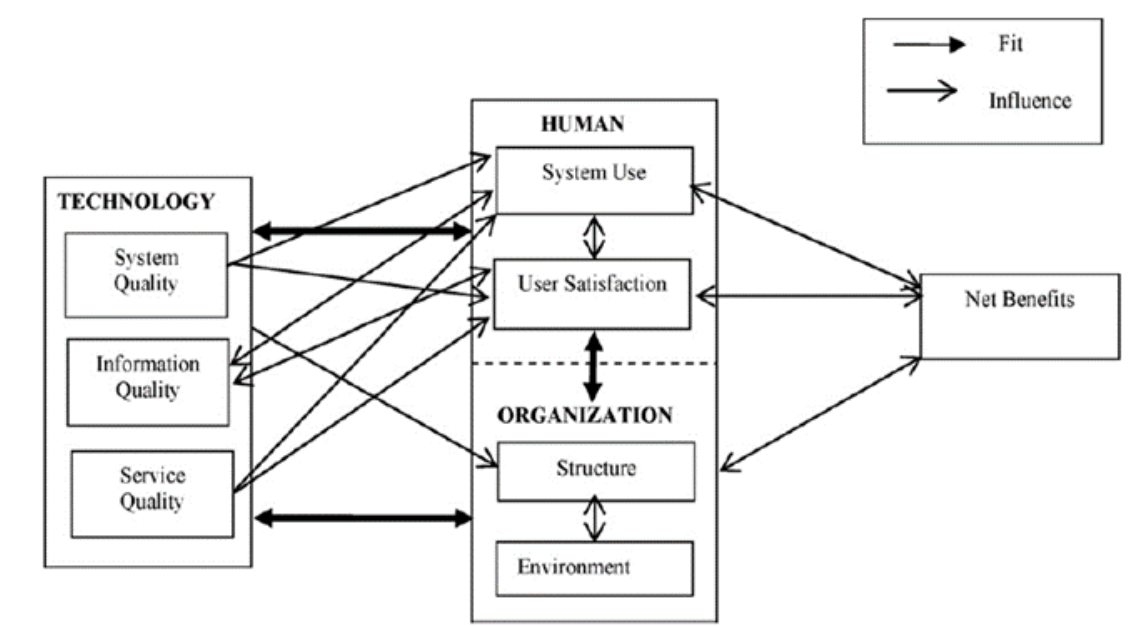

Gambar 1 Model human organization technology (hot) fit oleh yusof [10]

HOT Fit memiliki tiga aspek dan dimensi yang berbeda pada setiap aspeknya. Aspek technology (teknologi) memiliki tiga dimensi yaitu system quality (kualitas sistem), information quality (kualitas informasi) dan service quality (kualitas layanan). Aspek human (manusia) memiliki dua dimensi yaitu system use (penggunaan sistem) dan user satisfaction (kepuasan pengguna). User satisfaction (kepuasan pengguna) adalah keseluruhan evaluasi dari pengalaman pengguna dan dampak potensial dalam menggunakan sistem informasi. Aspek organization (organisasi) memiliki dua dimensi yaitu structure (struktur) dan environment (lingkungan). Ketiga aspek human, organization dan technology berhubungan dengan delapan dimensi kesuksesan sistem informasi yaitu system quality, information quality, service quality, system use, user satisfaction, environment, structure dan net benefit. Delapan dimensi tersebut saling berhubungan mempengaruhi satu dengan lainnya.

Melalui penelitian ini, diharapkan dapat memberikan kontribusi dalam bentuk akademis dan teoritis yang berupa rekomendasi model evaluasi sistem informasi yang tepat untuk mengevaluasi system E-Procurement Pemerintah Provinsi Bali dan faktor-faktor pendukung beserta kendala dalam penerapan sistem E-Procurement di Pemerintah Provinsi Bali.

\section{TINJAUAN PUSTAKA}

Beberapa penelitian terdahulu menyatakan bahwa variabel teknologi memiliki hubungan yang positif signifikan terhadap variabel pengguna [12][13][14]. Adapun dalam variabel teknologi terdapat 
indikator kualitas sistem (system quality), kualitas informasi (information quality), dan kualitas pelayanan (service quality), yang mana indikator tersebut mempengaruhi variabel pengguna yang memiliki indikator kegunaan sistem (system use) dan kepuasan pengguna (user satisfaction). Pada penelitian tersebut ditunjukkan bahwa kepuasan pengguna dan penggunaan sistem (variabel pengguna) dipengaruhi oleh kualitas sistem, informasi dan pelayanan (variabel teknologi) yang baik.

Pada penelitian pengembangan model HOT-Fit yang dilakukan oleh Yusof [10], ditunjukkan bahwa penggunaan sistem dan kepuasan pengguna merupakan anteseden langsung dari Net benefits (manfaat). Penggunaan sistem dan kepuasan pengguna adalah bagian dari variabel Pengguna, hal ini menunjukkan bahwa Pengguna memiliki pengaruh terhadap Manfaat yang ingin dicapai dalam penerapan sistem. Pada penerapan e-procurement, indikator pencapaian manfaat terpenuhi apabila indikator kepuasan pengguna dan penggunaan sistem tercapai. Yusof [15], menyatakan bahwa Organisasi memiliki pengaruh terhadap bagaimana perencanaan sistem dari tahap awal hingga tahap sistem tersebut dioperasikan. Diperlukan perencanaan dan strategi yang benar-benar sesuai dan memadai pada tahap perencanaan dan pengembangan sistem. Masalah yang dihadapi pada penelitian tersebut adalah tidak adanya planning (perencanaan) dan strategy (strategi) yang memadai oleh organisasi dalam implementasi sistem, sehingga menyebabkan banyak masalah yang dialami selama sistem tersebut dioperasikan. Hal ini menunjukkan bahwa peran organisasi sangat berpengaruh dalam pengembangan sistem atau teknologi.

Pada penelitian [10][16][12], ditunjukkan bahwa struktur organisasi dan lingkungan organisasi memiliki pengaruh terhadap manfaat yang ingin dicapai. Pada struktur organisasi terdapat indikator yang mempengaruhi manfaat, adapun indikator tersebut adalah dukungan oleh top management, perencanaan, komunikasi, strategi dan pelatihan.

Kepuasan pengguna dan penggunaan sistem dipengaruhi oleh kualitas sistem, informasi dan pelayanan yang baik. Semakin baik kualitas sistem dan pelayanan yang diberikan, maka nilai dari kepuasan pengguna juga akan semakin tinggi. Indikator pencapaian manfaat terpenuhi apabila indikator kepuasan pengguna dan penggunaan sistem tercapai. Organisasi berpengaruh terhadap perencanaan sistem dari tahap awal hingga tahap sistem tersebut dioperasikan. Selain itu, perencanaan dan strategi yang memadai juga perlu diperhatikan oleh organisasi agar tidak timbul masalah pada tahap perencanaan dan pengembangan sistem. Sebagian besar masalah yang dihadapi pada organisasi adalah tidak adanya planning (perencanaan) dan strategy (strategi) yang memadai dalam implementasi sistem, sehingga terdapat banyak masalah yang dialami selama sistem tersebut dioperasikan. Berbeda dengan penelitian yang dilakukan oleh Yusof et.al., yang menambahkan jika pada organisasi juga terdapat indikator lain yang mempengaruhi, yaitu dukungan top management, komunikasi dan pelatihan.

\section{METODE PENELITIAN}

Pada sub bab metode penelitian, dipaparkan mengenai metode dan konseptual model yang digunakan dalam mengumpulkan dan menganalisis data hasil penelitian, dimulai dari pengumpulan data, metode pengukuran dan rancangan analisis.

\subsection{Pengumpulan Data}

Penelitian ini merupakan penelitian kuantitatif, yang mana diperlukan data berupa angka yang digunakan untuk mengevaluasi pengaruh pengguna, organisasi dan teknologi terhadap manfaat dari EProcurement. Pengumpulan data dalam penelitian ini dilakukan dengan metode wawancara dengan pihak terkait yang menggunakan E-Procurement di Kantor Pemerintah Provinsi Bali. Adapun pihak terkait tersebut antara lain, personil LPSE yang bertugas sebagai penanggung jawab pemeliharaan sistem E-Procurement Pemerintah Provinsi Bali. Selain itu, pengumpulan data juga dilakukan melalui survey menggunakan Google Forms. Responden yang mengisi kuisioner pada Google Forms adalah pihak-pihak yang menggunakan E-Procurement, yaitu sebagai pihak pengguna dan personil LPSE. Pihak pengguna dikategorikan ke dalam pengguna internal dan eksternal. Jumlah responden yang mengisi kuisioner di Google Forms adalah 118 orang, tetapi hanya 108 yang diproses lebih lanjut. Sebanyak 10 kuisioner ditolak karena tidak memenuhi salah satu persyaratan, yaitu informan adalah orang yang baru pertama kali menggunakan E-Procurement, jadi belum banyak pengalaman yang dirasakan untuk memberikan jawaban atas pertanyaan-pertanyaan yang diajukan pada kuisioner. 


\subsection{Metode Pengukuran}

Kuisioner dirancang untuk mengumpulkan informasi yang dibutuhkan dari responden untuk penelitian. Kuisioner dibagi menjadi tiga aspek utama, yaitu informasi tentang latar belakang responden, informasi tentang pengalaman responden dalam menggunakan E-Procurement, dan informasi berdasarkan pada model konseptual. Mengadopsi metode skala likert untuk pengukuran kuesioner, yaitu $1=$ sangat tidak setuju, $2=$ tidak setuju, $3=$ netral, $4=$ setuju, dan $5=$ Sangat Setuju .

\subsection{Rancangan Analisis}

Tahapan dalam analisis data adalah merancang konseptual model terlebih dulu yang terdiri dari setiap variabel yang akan digunakan. Penelitian ini menggunakan 4 (empat) konstruksi model penelitian HOT-Fit, yaitu Human, Organization, Technology dan Net Benefits. Konseptual model yang digunakan diilustrasikan pada Gambar 2 [10].

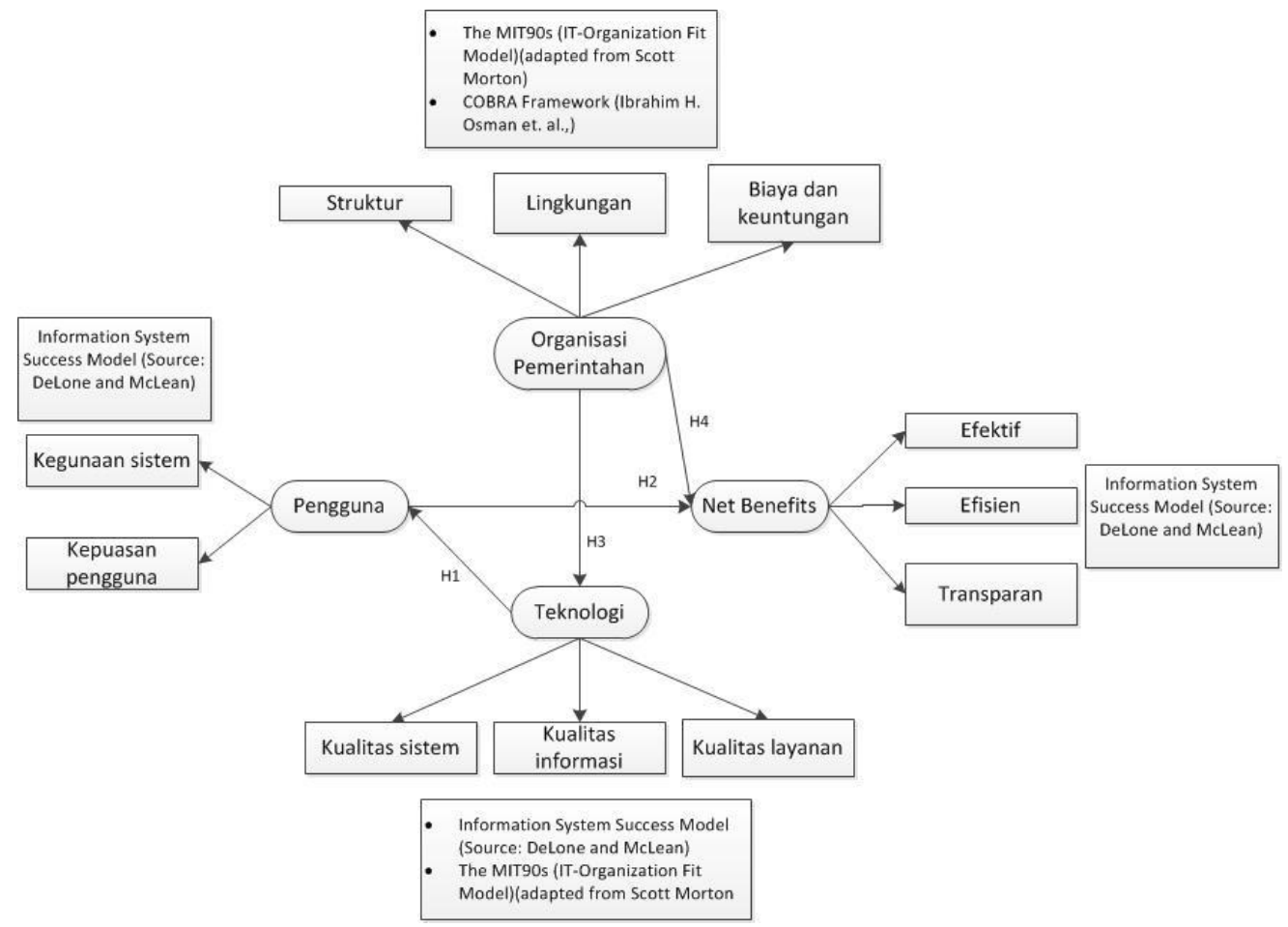

Gambar 2 Konseptual model penelitian

Berdasarkan konseptual model pada Gambar 2, hipotesis yang dikembangkan adalah sebagai berikut:

H1. Teknologi memiliki pengaruh positif dan signifikan terhadap Pengguna.

H2. Pengguna memiliki pengaruh positif dan signifikan terhadap Net Benefit.

H3. Organisasi Pemerintahan memiliki pengaruh positif dan signifikan terhadap Teknologi.

H4. Organisasi Pemerintahan memiliki pengaruh positif dan signifikan terhadap Manfaat.

Setelah konseptual model, lalu dirancang model untuk mengukur setiap indikator yang digunakan. Model penelitian ini terdiri dari 3 variabel independen dan 1 variabel dependen. Analisis dan pengolahan data pada penelitian ini juga menggunakan alat bantu statistik, yaitu SPSS dan GeSCA. SPSS digunakan untuk menguji kualitas, reliabilitas beserta linearitas dari semua instrumen yang digunakan pada konseptual model penelitian. Sedangkan, GeSCA digunakan dalam tahap analisis inferensial untuk mengetahui bagaimana hubungan antara masing-masing variabel sesuai dengan hipotesis yang telah dirancang.

\section{Uji Kualitas Instrumen}

Kuisioner yang digunakan harus baik dan relevan, oleh karena itu kuisioner yang baik dan relevan harus memenuhi dua persyaratan, yaitu valid dan reliable. Uji validitas adalah salah satu ukuran untuk mengukur sah/valid atau tidaknya hasil kuisioner. Suatu kuisioner dikatakan valid apabilan mempresentasikan apa yang ingin dicapai dari penyebaran kuisioner tersebut. 


\section{Uji Reliabilitas Instrumen}

Reliabilitas adalah ukuran kekonsistenan dan kestabilan kuisioner jika pengukuran dilakukan berulang-ulang. Pada uji reliabilitas, nilai "cronbach's alpha" diasumsikan sebagai nilai $r$ hasil. Menentukan suatu konstruk realibel atau tidak, maka dapat menggunakan batas nilai alpha sebagai berikut:

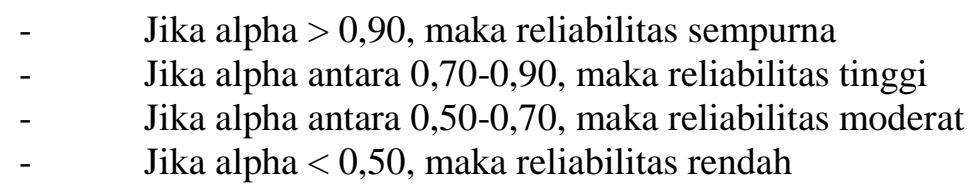

\section{Uji Linearitas}

Uji linearitas bertujuan untuk mengetahui apakah dua variabel mempunyai hubungan yang linear secara signifikan atau tidak. Data yang baik seharusnya terdapat hubungan yang linear antara variabel predictor $(\mathrm{X})$ dengan variabel kriterium $(\mathrm{Y})$. Beberapa referensi menyebutkan bahwa uji linearitas digunakan sebagai prasyarat dalam analisis korelasi atau regresi linear.

\section{Analisis Inferensial}

Analisis inferensial dilakukan dengan menggunakan tools GeSCA. GeSCA dipilih karena model dalam penelitian ini memiliki variabel laten dengan indikator yang bersifat reflektif.

a. Convergent Validity

Validitas ini menggambarkan ukuran korelasi antara skor indikator reflektif dengan skor variabel latennya. Suatu variabel laten dinilai memiliki convergent validity baik jika nilai loading factors $\geq 0,7$ dan signifikan. Apabila nilai loading tidak valid dan signifikan, maka indikator dapat di drop untuk mendapatkan model yang sesuai.

\section{b. Discriminant Validity}

Validitas ini pada indikator reflektif berdasarkan pada nilai AVE, yaitu membandingkan nilai square root of average extracted (AVE) setiap variabel laten dengan korelasi antar per variabel laten lainnya dalam model. jika square root of average variance extracted (AVE) variabel laten lebih besar dari korelasi dengan seluruh variabel laten lainnya, maka dikatakan memiliki discriminant validity yang baik.

\section{c. Composite Reliability dan AVE}

Blok indikator yang mengukur suatu konstruk laten dapat dievaluasi dengan dua macam ukuran, yaitu internal consistency dan cronbach's alpha dengan menggunakan output yang dihasilkan oleh GeSCA. Nilai composite reliability yang direkomendasikan $\geq 0,70$. Average Variance Extracted (AVE) dikatakan baik dalam mewakili skor data asli jika diatas 0,5 atau $\geq 0,5$. Jika keduanya memiliki nilai yang baik (cronbahcs alpha $\geq 0,70$ dan $\mathrm{AVE} \geq 0,50$ ), maka konstruk atau variabel reliabel.

d. Indentifikasi Overall Goodness of FIT

Pada tahap ini dilakukan identifikasi goodness of fit model structural dan nilai R2 dari hasil pengolahan data menggunakan aplikasi GeSCA.

\section{e. Identifikasi R2}

Identifikasi $\mathrm{R}$ square bertujuan untuk mengetahui kemampuan menjelaskan kepada masing-masing variabel teknologi, pengguna, organisasi dan Net benefits. Jika nilai R2 mendekati 1, diartikan bahwa variabel independen sangat mendukung terhadap variabel dependen.

f. Identifikasi Overall Model

Overall model adalah model pada GeSCA yang melibatkan struktural serta model pengukuran secara terintegrasi.

\section{HASIL DAN PEMBAHASAN}

Pada hasil dan pembahasan, dipaparkan mengenai data dari hasil kuisioner yang telah diisi oleh responden. Adapun data yang dipaparkan meliputi frekuensi dan persentase dari profil informan yang ditunjukkan pada Tabel 1, hasil pengujian kualitas instrumen yang ditunjukkan pada Tabel 2, hasil pengujian reliabilita yang ditunjukkan pada Tabel 3, hasil pengujian linearitas yang ditunjukkan pada Tabel 4, hasil analisis inferensial yang ditunjukkan pada Tabel 5 sampai Tabel 10, dan hasil pengujian hipotesis yang ditunjukkan pada Tabel 11. Berikut ini adalah data dari profil informan yang ditunjukkan pada Tabel 1. 
Tabel 1 Profil Informan

\begin{tabular}{lcc}
\hline \multicolumn{1}{c}{ Keterangan } & Frekuensi & Persentase \\
\hline Jenis Kelamin : & & \\
- Laki-laki & 48 & $55 \%$ \\
- Perempuan & 60 & $45 \%$ \\
- Jumlah & 108 & $100 \%$ \\
Usia : & & \\
- 20-30 tahun & 78 & $72 \%$ \\
- 31-40 tahun & 30 & $28 \%$ \\
- Jumlah & 108 & $100 \%$ \\
Pengalaman Menggunakan E-Proc : & & \\
- Ya (Pernah) & 93 & $86 \%$ \\
- Tidak (Tidak Pernah) & 15 & $14 \%$ \\
- Jumlah & 108 & $100 \%$ \\
Frekuensi Menggunakan E-Proc : & & \\
- Sering & 66 & $66 \%$ \\
- Jarang & 42 & $34 \%$ \\
- Jumlah & 108 & $100 \%$ \\
\hline
\end{tabular}

Sumber: Data Diolah (2019)

Pengujian selanjutnya yang dilakukan adalah pengujian kualitas instrumen, yang mana tools yang digunakan pada pengujian ini adalah SPSS. Adapun instrumen yang diuji adalah variabel pengguna, organisasi dan teknologi.

\subsection{Hasil Pengujian Kualitas Instrumen}

Pengujian kualitas instrumen dilakukan dengan menggunakan SPSS. Hasil pengujian validitas kualitas instrumen pada variabel Teknologi, Pengguna, Organisasi dan Net Benefits memiliki nilai yang seluruhnya lebih besar daripada $r$-table, atau $\mathrm{r}^{\text {hitung }}>\mathrm{r}^{\text {table }}$. Nilai $\mathrm{r}$-tabel adalah 0,189 , sehingga dapat dikatakan seluruh variabel tersebut valid. Nilai r-tabel ini diperoleh dari perhitungan nilai $\mathrm{df}=\mathrm{N}$ 2 dengan tingkat signifikansi 0,05 , yang mana $\mathrm{N}=108$. Hal ini menunjukkan bahwa instrumen tersebut dapat digunakan untuk analisis selanjutnya. Nilai hasil pengujian kualitas dari masing-masing instrumen ditampilkan pada tabel 2.

Tabel 2 Hasil Uji Validitas Variabel Teknologi, Pengguna, Organisasi dan Net Benefits

\begin{tabular}{ccccc}
\hline Variabel & Indikator & Nilai & r table & Keterangan \\
\hline Teknologi & Kualitas Sistem & $.934^{* *}$ & 0,189 & Valid \\
& Kualitas Informasi & $.958^{* *}$ & 0,189 & Valid \\
& Kualitas Layanan & $.817^{* *}$ & 0,189 & Valid \\
& Penggunaan Sistem & $.935^{* *}$ & 0,189 & Valid \\
& Kepuasan Pengguna & & & \\
Organisasi & Struktur Organisasi & $.873^{* *}$ & 0,189 & Valid \\
Pemerintah & Lingkungan & $.577^{* *}$ & 0,189 & Valid \\
& Organisasi & & & \\
& Keuangan dan & $.837^{* *}$ & 0,189 & Valid \\
& Keuntungan & & & \\
Net Benefits & Efektif & $.926^{* *}$ & 0,189 & Valid \\
& Efisien & $.946^{* *}$ & 0,189 & Valid \\
& Transparan & $.916^{* *}$ & 0,189 & Valid \\
\hline
\end{tabular}

Sumber: Output SPSS (2019)

\subsection{Hasil Pengujian Reliabilitas}

Pengujian reliabilitas ditujukan untuk mengukur tingkan konsistensi dan kestabilan kuisioner jika dilakukan pengukuran secara berulang. Nilai "cronbach's alpha" diasumsikan sebagai nilai $\mathrm{r}$ hasil. 
Hasil dari pengujian reliabilitas menghasilkan nilai "cronbach's alpha" yang keseluruhannya >0,5. Hal ini menyatakan data pada kuisioner reliable atau dapat dipercaya. Tabel 3 berikut adalah hasil dari pengujian reliabilitas dari variabel Teknologi, Pengguna, Organisasi dan Net Benefits.

Tabel 3 Hasil Uji Reliabilitas Variabel Teknologi, Pengguna, Organisasi dan Net Benefits

\begin{tabular}{ccc}
\hline Variabel & $\begin{array}{c}\text { Cronbach's alpha } \\
(\mathbf{N = 1 0 8})\end{array}$ & Keterangan \\
\hline Teknologi & 0.919 & Reliabilitas Sempurna \\
Pengguna & 0.818 & Reliabilitas Tinggi \\
Organisasi & 0.800 & Reliabilitas Tinggi \\
Net Benefits & 0.931 & Reliabilitas Sempurna \\
\hline
\end{tabular}

Sumber: Output SPSS (2019)

\subsection{Hasil Pengujian Linearitas}

Uji linearitas bertujuan untuk mengetahui apakah dua variabel mempunyai hubungan yang linear secara signifikan atau tidak. Jika nilai $\mathrm{F}_{\text {hitung }}<\mathrm{F}_{\text {tabel}}$, maka terdapat hubungan yang linear secara signifikan antara variabel yang terkait. Melihat hasil dari $\mathrm{F}_{\text {hitung }}$ yang diperoleh, seluruh nilainya lebih kecil atau kurang dari nilai pada $\mathrm{F}_{\text {tabel }}$ yang tertera. Kesimpulan dari hasil ini adalah semua variabel memiliki hubungan yang linear sesuai dengan hipotesis. Tabel 4 adalah hasil dari uji linearitas dari masing-masing hipotesis.

Tabel 4 Hasil Uji Linearitas Hipotesis

\begin{tabular}{ccll}
\hline Variabel & $\mathbf{F}_{\text {hitung }}$ & Sig & $\mathbf{F}_{\text {tabel }}$ \\
\hline Teknologi * Pengguna & 1.086 & .430 & 2,25 \\
Pengguna * Net Benefits & .912 & .557 & 2,22 \\
Organisasi * Teknologi & 1.504 & .204 & 2,27 \\
Organisasi * Net Benefits & .760 & .711 & 2,27 \\
\hline Suni
\end{tabular}

Sumber: Output SPSS (2019)

\subsection{Hasil Analisis Inferensial}

Analisis inferensial dilakukan dengan menggunakan tools GeSCA. GeSCA dipilih karena model dalam penelitian ini memiliki variabel laten dengan indikator yang bersifat reflektif.

\section{Convergent Validity}

Validitas ini menggambarkan ukuran korelasi antara skor indikator reflektif dengan skor variabel latennya. Suatu variabel laten dinilai memiliki convergent validity baik jika nilai loading factors $\geq 0,7$ dan signifikan. Apabila nilai loading tidak valid dan signifikan, maka indikator dapat di drop untuk mendapatkan model yang sesuai. Berikut ini hasil convergent validity dari setiap variabel yang dihitung menggunakan GeSCA.

Tabel 5 Hasil Uji Convergent Validity

\begin{tabular}{ccccc}
\hline Variabel & Indikator & $\begin{array}{c}\text { Loading } \\
\text { Factor }\end{array}$ & AVE & Alpha \\
\hline \multirow{3}{*}{ Teknologi } & X1.1 & 0,909 & & \\
& X1.2 & 0,925 & 0,816 & 0,8872 \\
& X1.3 & 0,875 & & \\
Pengguna & X2.1 & 0,868 & 0,819 & 0,7858 \\
& X2.2 & 0,940 & & \\
Organisasi & X3.1 & 0,913 & & \\
& X3.2 & 0,780 & 0,757 & 0,8419 \\
& X3.3 & 0,911 & & \\
Net & Y1.1 & 0,913 & & \\
Benefits & Y1.2 & 0,780 & 0,839 & 0,9366 \\
& Y1.3 & 0,911 & & \\
\hline
\end{tabular}


Convergent validity untuk semua indikator dari variabel Teknologi, Pengguna, Organisasi dan Net Benefits memiliki nilai loading factor $\geq 0,7$. Hal ini menunjukkan bahwa seluruh indikator yang ada di masing-masing variabel adalah baik dan signifikan, maka seluruh indikator tersebut dapat digunakan.

\section{Discriminant Validity}

Validitas ini pada indikator reflektif berdasarkan pada nilai AVE, yaitu membandingkan nilai square root of average extracted (AVE) setiap variabel laten dengan korelasi antar per variabel laten lainnya dalam model. jika square root of average variance extracted (AVE) variabel laten lebih besar dari korelasi dengan seluruh variabel laten lainnya, maka dikatakan memiliki discriminant validity yang baik.

Tabel 6 Hasil Uji Discriminant Validity

\begin{tabular}{lccccccc}
\hline Variabel & AVE & $\sqrt{ }$ AVE & \multicolumn{5}{c}{ Correlations of Latent Variables (SE) } \\
& & & Teknologi & Pengguna & Organisasi & Net Benefits & Ket \\
\hline Teknologi & 0.816 & 0,903 & 1 & & & & Baik \\
Pengguna & 0.819 & 0,905 & 0.905 & 1 & & & Baik \\
Organisasi & 0.757 & 0,870 & 0.870 & 0.762 & 1 & & Baik \\
Net Benefits & 0.839 & 0,916 & 0.592 & 0.715 & 0.723 & 1 & Baik \\
\hline
\end{tabular}

Nilai akar kuadrat pada variabel teknologi, pengguna, organisasi dan Net benefits lebih besar dari relasi masing-masing variabel, sehingga discriminant validity pada variabel teknologi, pengguna, organisasi dan Net benefits dianggap baik.

\section{Composite Reliability dan AVE}

Blok indikator yang mengukur suatu konstruk laten dapat dievaluasi dengan dua macam ukuran, yaitu internal consistency dan cronbach's alpha dengan menggunakan output yang dihasilkan oleh GeSCA. Nilai composite reliability yang direkomendasikan $\geq 0,70$. Average Variance Extracted (AVE) dikatakan baik dalam mewakili skor data asli jika diatas 0,5 atau $\geq 0,5$. Jika keduanya memiliki nilai yang baik (cronbahcs alpha $\geq 0,70$ dan $A V E \geq 0,50$ ), maka konstruk atau variabel reliabel. Berikut hasil dari GeSCA.

Tabel 7 Hasil Composite Realibility

\begin{tabular}{ccc}
\hline Variable & AVE & Alpha \\
\hline Teknologi & 0.887 & 0.816 \\
Pengguna & 0.786 & 0.819 \\
Organisasi & 0.842 & 0.757 \\
Net Benefits & 0.937 & 0.839 \\
\hline
\end{tabular}

Pada tabel 7, semua variabel memiliki nilai cronbach alpha lebih dari 0,7, dan nilai AVE pada masing-masing variabel memiliki nilai lebih dari 0,5 . Hal ini menunjukkan bahwa semua variabel tersebut reliabel.

\section{Identifikasi Overall Goodness of FIT}

Pada tahap ini dilakukan identifikasi goodness of fit model structural dan nilai $\mathrm{R}^{2}$ dari hasil pengolahan data menggunakan aplikasi GeSCA. Berikut ini adalah hasil analisisnya.

Tabel 8 Hasil Identifikasi Overall Goodness of FIT

\begin{tabular}{cccc}
\hline Model Fit & Cut-off & Nilai & Keterangan \\
\hline FIT & $0-1$ & 0.728 & Baik \\
AFIT & $0-1$ & 0.709 & Baik \\
NPAR & - & 28 & Jumlah parameter \\
& & & bebas \\
\hline
\end{tabular}


Berdasarkan tabel 8 yang didapatkan dari perhitungan GeSCA, nilai yang ada akan dipaparkan sebagai berikut:

FIT

Nilai FIT mengukur seberapa besar varian data yang dapat dijelaskan oleh model. nilai FIT berkisar antara 0-1, jika nilai FIT semakin mendekati angka1, maka dapat dikatakan bahwa model semakin baik menjelaskan fenomena yang diteliti. Pada tabel 3.12 diketahui bahwa model yang terbentuk dapat menjelaskan semua variabel yang ada sebesar 0,728. Hal ini berarti teknologi, pengguna, organisasi dan Net benefits dapat dijelaskan oleh model sebesar 72,8\% dan sisanya 27,2\% dapat dijelaskan oleh variabel lainnya yang tidak ada pada model.

AFIT

Nilai AFIT dapat menunjukkan variasi yang dimungkinkan dari pergerakan model. Berdasarkan tabel 5.16, didapatkan nilai AFIT sebesar 0,709. Dapat dikatakan model sudah baik dalam dalam menjelaskan fenomena yang diteliti. Berdasarkan nilai AFITnya, model mampu menjelaskan 70,9\% bahwa teknologi, pengguna, dan organisasi mampu mempengaruhi pencapaian kesuksesan Net benefits.

\section{NPAR}

Nillai NPAR (number of free parameters estimated) menunjukkan banyaknya parameter bebas yang digunakan dalam perhitungan GeSCA, termasuk weight loadings dan path coefficient. Pada penelitian ini, parameter bebas berjumlah 28 .

\section{Identifikasi $\mathbf{R}^{2}$}

Identifikasi $\mathrm{R}$ square bertujuan untuk mengetahui kemampuan menjelaskan kepada masingmasing variabel teknologi, pengguna, organisasi dan Net benefits. Jika nilai $\mathrm{R}^{2}$ mendekati 1 , diartikan bahwa variabel independen sangat mendukung terhadap variabel dependen. Berikut ini adalah hasil identifikasi $\mathrm{R}^{2}$ dengan menggunakan GeSCA.

Tabel 9 Hasil Identifikasi R square

R square of Latent Variable

\begin{tabular}{cc}
\hline Teknologi & 0.619 \\
Pengguna & 0.673 \\
Organisasi & 0 \\
Net Benefits & 0.587 \\
\hline
\end{tabular}

Berdasarkan tabel 9, dapat dilihat bahwa nilai $\mathrm{R}^{2}$ pada Teknologi adalah 0,619 , yang berarti variabilitas teknologi dapat dijelaskan oleh variabilitas organisasi sebesar $61,9 \%$. Nilai $\mathrm{R}^{2}$ pada pengguna adalah 0,673 , yang mana variabilitas pengguna dapat dijelaskan oleh variabilitas teknologi sebesar 67,3\%. Sedangkan Net Benefits adalah sebesar 0,587 yang berarti variablilitas Net Benefits dapat dijelaskan oleh variabilitas teknologi, pengguna dan organisasi sebesar 58,7\%.

Identifikasi Overall Model

Overall model adalah model pada GeSCA yang melibatkan struktural serta model pengukuran secara terintegrasi. Berikut ini adalah hasil identifikasi dari overall model.

Tabel 10 Hasil Identifikasi Overall Model

\begin{tabular}{cccc}
\hline Model Fit & Cut-off & Nilai & Keterangan \\
\hline GFI & $>0,90$ & 0.995 & Sesuai \\
SRMR & $\leq 0,08$ & 0.104 & Tidak Sesuai \\
\hline
\end{tabular}

Nilai GFI (goodness of fit Index) sebesar 0,995. Hal ini diartikan bahwa model sudah sesuai karena sangat mendekati nilai 1. Untuk nilai SRMR (Standardized Root Mean Square Residual) pada penelitian ini menunjukkan angka 0,104 dan dapat diartikan bahwa model SRMR tidak sesuai (poor fit). Hal ini dapat disebabkan oleh variasi nilai yang didapat kurang baik akibat jumlah sample yang kurang banyak. 


\subsection{Hasil Pengujian Hipotesis}

Pengujian hipotesis dilakukan dengan melihat nilai path coefficient pada model struktural. Berikut ini adalah nilai path coefficient dari hasil output GeSCA.

Tabel 11 Hasil Identifikasi Overall Model

\begin{tabular}{cccccc}
\hline & Estimate & SE & 95\%CI_LB & 95\%CI_UB & CR \\
\hline $\begin{array}{c}\text { Teknologi- } \\
\text { >Pengguna }\end{array}$ & 0.8203 & 0.053 & 0.7444 & 0.878 & $15.47^{*}$ \\
$\begin{array}{c}\text { Pengguna->Net } \\
\begin{array}{c}\text { Benefits } \\
\text { Organisasi- }\end{array}\end{array}$ & 0.3907 & 0.196 & 0.0524 & 0.648 & $1.99^{*}$ \\
$\begin{array}{c}>\text { Teknologi } \\
\text { Organisasi- }\end{array}$ & 0.7869 & 0.057 & 0.7214 & 0.8686 & $13.80^{*}$ \\
$>$ >Net Benefits & 0.4254 & 0.248 & 0.1791 & 0.7628 & $1.71^{*}$ \\
\hline significant at .05 level & & & &
\end{tabular}

Jika digambarkan pada model empiris penelitian, maka akan menjadi seperti pada Gambar 3 dibawah ini.

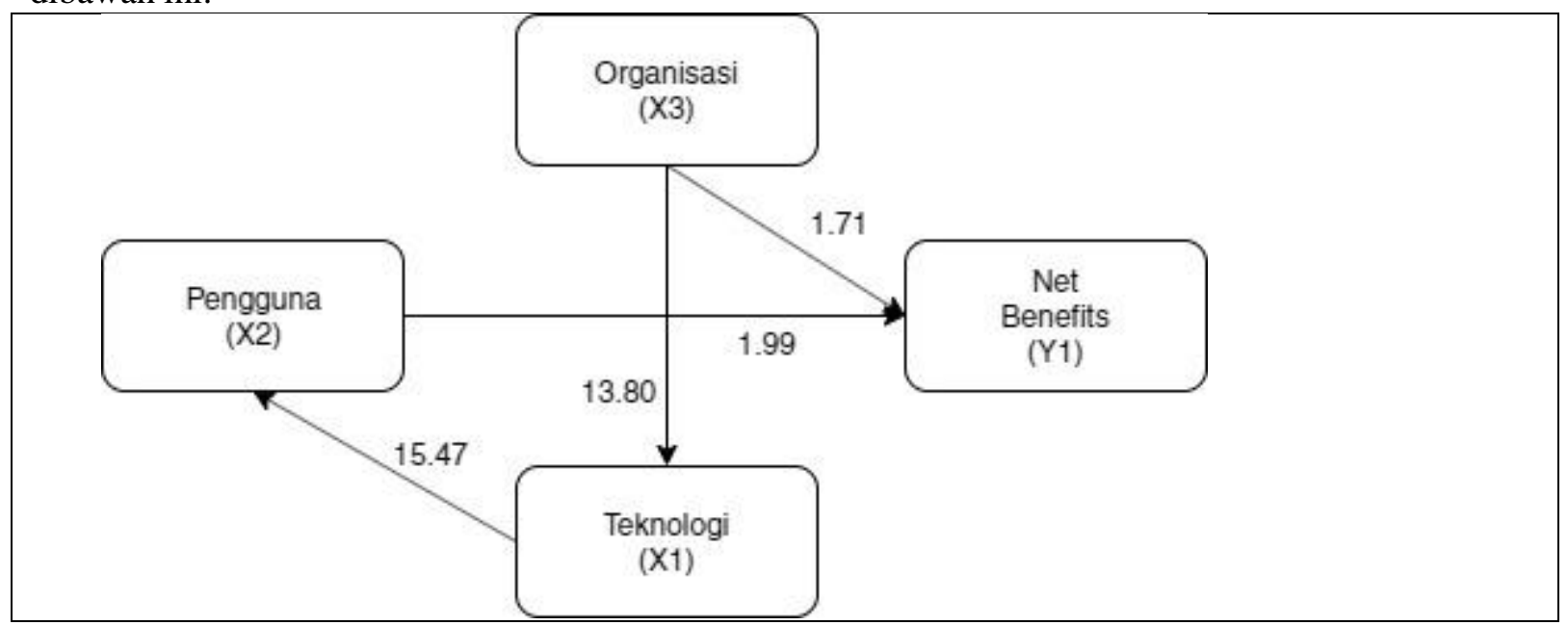

Gambar 3 Model uji hipotesis

\subsection{Pembahasan}

Sub bab kali ini menjelaskan mengenai pembahasan dari hasil uji hipotesis yang telah dilakukan dan dipaparkan datanya di sub bab hasil. Seluruh data hasil uji hipotesis yang dibahas, mengacu pada data real yang telah melalui beberapa proses olah data menggunakan tools SPSS dan GeSCA.

\section{Teknologi memiliki hubungan positif dan signifikan terhadap Pengguna}

Berdasarkan nilai path coefficient pada table 5.19 diatas, diketahui bahwa nilai estimate yang dihasilkan adalah 0,8203, kemudian nilai SE adalah 0,053 dan nilai CR adalah 15,47. Korelasi atau hubungan pengaruh dapat dilihat dari nilai estimate dan critical ratio (CR). Berdasarkan pengamatan pada nilai koefisien jalur dapat disimpulkan bahwa terdapat pengaruh positif antara teknologi dengan pengguna dilihat dari nilai estimate dan signifikan ditandai dengan adanya tanda $(*)$ pada nilai CR. Berdasarkan hasil tersebut, hipotesis 1 yang menyatakan bahwa teknologi memilki hubungan positif dan signifikan terhadap pengguna diterima. Hasil uji hipotesis ini memberikan pengertian bahwa teknologi yang digunakan pada penelitian ini, yaitu sistem E-Procurement membantu pengguna dalam proses pengadaan barang dan jasa. Adapun pengguna dari sistem ini adalah penyedia eksternal, internal dan personil LPSE. Secara fungsi, sistem E-Procurement sejauh ini telah tercapai sebanyak $90 \%$. Menurut hasil kuesioner, pengguna menyatakan bahwa dengan adanya e-procurement kegiatan pengadaan barang dan jasa menjadi lebih mudah dan sangat membantu pengguna dalam melengkapi dokumen yang diperlukan tanpa perlu lagi menyediakan banyak dokumen dalam bentuk hardcopy, dan juga sangat menghemat waktu serta biaya. Namun ada beberapa hal yang masih sering menjadi 
kendala yang dialami pengguna terkait sistem, yaitu tidak bisa login ke sistem dan error saat penggunaan sistem.

\section{Pengguna memiliki hubungan positif dan signifikan terhadap Net Benefits}

Berdasarkan nilai path coefficient pada tabel 5.19 diatas, diketahui bahwa nilai estimate yang dihasilkan adalah 0.3907, kemudian nilai SE adalah 0,196 dan nilai CR adalah 1.99. Korelasi atau hubungan pengaruh dapat dilihat dari nilai estimate dan critical ratio (CR). Berdasarkan pengamatan pada nilai koefisien jalur dapat disimpulkan bahwa terdapat pengaruh positif antara pengguna dengan Net benefits dilihat dari nilai estimate dan signifikan ditandai dengan adanya tanda (*) pada nilai CR. Berdasarkan hasil tersebut, hipotesis 2 yang menyatakan bahwa pengguna memilki hubungan positif dan signifikan terhadap Net benefits diterima. Hasil uji hipotesis ini memberikan pengertian bahwa pengguna merasakan manfaat yang diberikan dengan adanya sistem E-Procurement ini. Sesuai dengan tujuan diterapkannya sistem E-Procurement, adapun manfaat yang dirasakan oleh pengguna yaitu mempercepat proses pengadaan barang dan jasa, mengurangi beberapa tahap yang dulunya masih dilaksanakan secara manual, mengurangi pengeluaran kertas, memberikan informasi yang relevan secara real time, dan secara keseluruhan dengan penerapan sistem ini juga telah mencapai prinsip transparansi sebagaimana yang direncanakan sebelumnya. Melihat hasil kuisioner dari pengguna, pengguna menyatakan banyak manfaat yang dirasakan dan merasa terbantu dalam melaksanakan proses pengadaan barang dan jasa dari awal hingga akhir. Kepuasan pengguna menjadi salah satu indikator yang berpengaruh paling besar, adapun dilihat dari data di Sistem Informasi Administrasi Pengunjung milik Pemerintah Provinsi Bali pada bulan Juli hingga November 2019 saat ini, tingkat kepuasan pengguna terhadap sistem ada di tingkat Sangat Puas. Sebanyak 490 pengguna merasakan sangat puas dalam menggunakan sistem E-Procurement Pemerintah Provinsi Bali.

\section{Organisasi memiliki hubungan positif dan signifikan terhadap Teknologi}

Berdasarkan nilai path coefficient pada tabel 5.19 diatas, diketahui bahwa nilai estimate yang dihasilkan adalah 0,816, kemudian nilai SE adalah 0,057 dan nilai CR adalah 13.80. Korelasi atau hubungan pengaruh dapat dilihat dari nilai estimate dan critical ratio (CR). Berdasarkan pengamatan pada nilai koefisien jalur dapat disimpulkan bahwa terdapat pengaruh positif antara organisasi pemerintahan dengan teknologi dilihat dari nilai estimate dan signifikan ditandai dengan adanya tanda (*) pada nilai CR. Berdasarkan hasil tersebut, hipotesis 3 yang menyatakan bahwa organisasi pemerintahan memilki hubungan positif dan signifikan terhadap teknologi diterima. Hasil uji hipotesis ini memberikan pengertian bahwa penerapan sistem E-Procurement ini mendapat dukungan yang positif dari Organisasi, yang mana organisasi yang dimaksud pada penelitian ini adalah Pemerintah Provinsi Bali. Seluruh aspek yang menjadi indikator pada organisasi sangat berpengaruh, karena dengan adanya strategi dan pengembangan yang direncanakan dengan baik oleh organisasi pemerintahan, maka implementasi E-Procurement akan berjalan sesuai dengan yang direncanakan jika dilihat dari sisi teknisnya. Pemerintah Provinsi Bali telah menggunakan sistem E-Procurement selama 9 tahun, dan selama 9 tahun juga banyak kritik dan saran oleh pengguna terhadap sistem. Namun, pihak Pemerintah tidak hanya diam, dan langsung memperbaiki kekurangan sistem E-Procurement ini sesuai dengan kritik dan saran yang diberikan. Kritik yang banyak diberikan terkait dengan sistem adalah error yang sering terjadi saat pengguna akan login, dan tidak adanya petunjuk penggunaan pada sistem. Namun semua masalah tersebut telah diatasi oleh pihak LPSE dengan melampirkan userguide pada sistem.

\section{Organisasi Pemerintah memiliki hubungan positif dan signifikan terhadap Net Benefits}

Berdasarkan nilai path coefficient pada tabel 5.19 diatas, diketahui bahwa nilai estimate yang dihasilkan adalah 0.4254 , kemudian nilai SE adalah 0.248 dan nilai CR adalah 1.71. Korelasi atau hubungan pengaruh dapat dilihat dari nilai estimate dan critical ratio (CR). Berdasarkan pengamatan pada nilai koefisien jalur dapat disimpulkan bahwa terdapat pengaruh positif antara organisasi dengan Net benefits dilihat dari nilai estimate dan signifikan ditandai dengan adanya tanda (*) pada nilai CR. Berdasarkan hasil tersebut, hipotesis 4 yang menyatakan bahwa organisasi pemerintah memilki hubungan positif dan signifikan terhadap pengguna diterima. Hasil uji hipotesis ini memberikan pengertian bahwa pihak Organisasi, yang mana yang dimaksud pada penelitian ini adalah Pemerintah Provinsi Bali memberikan pelayanan penuh kepada pengguna, sehingga pengguna merasakan manfaat yang diharapkan dengan adanya sistem E-Procurement. Pelayanan yang diberikan tidak hanya pada saat pengguna memberikan aduan terkait error pada sistem, tetapi juga dengan memberikan pelatihan 
atau training secara rutin kepada para pengguna sebelum menggunakan sistem E-Procurement. Melalui pelayanan tersebut, pengguna menjadi merasakan banyak manfaat yang diberikan oleh sistem E-Procurement, hasil uji hipotesis ini sesuai dengan hasil penelitian sebelumnya yang menyatakan bahwa organisasi berpengaruh positif dan signifikan terhadap pencapaian Net benefits.

\section{KESIMPULAN}

Kesimpulan yang dapat ditarik berdasarkan rumusan masalah yang diajukan yaitu mengenai faktor manakah yang mendukung penerapan sistem E-Procurement di Kantor Gubernur Provinsi Bali adalah faktor Teknologi, Pengguna dan Organisasi. Sedangkan, faktor yang menjadi kendala sejauh ini yaitu masih ada beberapa tahapan pada proses pengadaan barang dan jasa yang belum terlaksana by sistem atau masih manual. Hal ini dibuktikan berdasarkan dengan hasil wawancara langsung kepada kepala LPSE dan juga berdasarkan hasil pengisian kuisioner oleh pengguna sistem. Kesimpulan hasil wawancara dan kuisioner tersebut adalah sebagai berikut: Pertama, hipotesis 1 yang menyatakan bahwa teknologi memilki hubungan positif dan signifikan terhadap pengguna diterima. Secara fungsi, persentase Sistem E-Procurement membantu pengguna dalam proses pengadaan barang dan jasa telah mencapai 90\%. Pengguna menyatakan bahwa dengan adanya E-procurement kegiatan pengadaan barang dan jasa menjadi lebih mudah dan sangat membantu dalam melengkapi dokumen yang diperlukan tanpa perlu lagi menyediakan banyak dokumen dalam bentuk hardcopy. Selain itu juga sangat menghemat waktu serta biaya, namun ada beberapa hal yang masih sering dialami pengguna terkait sistem, yaitu tidak bisa login ke sistem dan error saat penggunaan sistem. Kendala ini sudah diatasi oleh tim LPSE dengan menugaskan beberapa admin untuk standby jika ada pengaduan dari pengguna terkait error pada sistem atau tidak bisa login.

Kedua, hipotesis 2 yang menyatakan bahwa pengguna memiliki hubungan positif dan signifikan terhadap Net benefits diterima. Kepuasan pengguna menjadi salah satu indikator yang berpengaruh paling besar, dilihat dari data di Sistem Informasi Administrasi Pengunjung milik Pemerintah Provinsi Bali pada bulan Juli hingga November 2019 saat ini, tingkat kepuasan pengguna terhadap sistem ada di tingkat Sangat Puas. Sebanyak 490 pengguna merasakan sangat puas dalam menggunakan sistem E-Procurement Pemerintah Provinsi Bali. Melalui hasil kepuasan pengguna tersebut, dapat disimpulkan bahwa pengguna merasakan net benefits yang diberikan oleh adanya E-Procurement.

Ketiga, hipotesis 3 yang menyatakan bahwa organisasi pemerintahan memilki hubungan positif dan signifikan terhadap teknologi diterima. Penerapan sistem E-Procurement telah mendapat dukungan yang positif dari Pemerintah Provinsi Bali. Dengan adanya strategi dan pengembangan yang direncanakan dengan baik oleh Pemerintah Provinsi Bali, menjadikan implementasi EProcurement berjalan sesuai dengan yang direncanakan jika dilihat dari sisi teknisnya. Pemerintah Provinsi Bali telah menggunakan sistem E-Procurement selama 9 tahun, dan selama 9 tahun juga banyak kritik dan saran oleh pengguna terhadap sistem. Kritik yang banyak diberikan terkait dengan sistem adalah error yang sering terjadi dan tidak adanya petunjuk penggunaan pada sistem, namun semua masalah tersebut telah diatasi oleh pihak LPSE dengan melampirkan userguide pada sistem.

Keempat, hipotesis 4 yang menyatakan bahwa organisasi pemerintah memiliki hubungan positif dan signifikan terhadap pengguna diterima. Pemerintah Provinsi Bali telah memberikan pelayanan penuh kepada pengguna, sehingga pengguna merasakan manfaat yang diharapkan dengan adanya sistem E-Procurement. Pelayanan yang diberikan tidak hanya pada saat pengguna memberikan aduan terkait error pada sistem, tetapi juga dengan memberikan pelatihan atau training secara rutin setiap satu minggu sekali kepada para pengguna sebelum menggunakan sistem E-Procurement. Pelayanan maksimal tersebut menyatakan bahwa Pemerintah Provinsi Bali dengan sungguh-sungguh menerapkan E-Procurement dengan baik, sehingga pengguna merasakan manfaat yang diberikan oleh sistem.

\section{REFERENSI}

[1] M. Suleiman, "Adoption of E-procurement and Value Addition: Tanzanian context," Eur. J. Bus. Manag. www.iiste.org ISSN, vol. 7, no. 14, pp. 145-153, 2015.

[2] R. A. Komakech, "Public Procurement in Developing Countries : Objectives, Principles and Required Professional Skills," vol. 6, no. 8, pp. 20-29, 2016.

[3] R. Hidayat, "PENERAPAN e-PROCUREMENT DALAM PROSES PENGADAAN 
BARANG DAN JASA PEMERINTAH GUNA MENDUKUNG KETAHANAN TATA PEMERINTAHAN DAERAH (Studi pada Unit Layanan Pengadaan Barang dan Jasa Pemerintah Kabupaten Penajam Paser Utara Provinsi Kalimantan Timur)," J. Ketahanan Nas., vol. 21, no. 2, p. 118, 2015.

[4] S. Dyah Nayabarani, "MEMBANGUN TRANSPARANSI PENGADAAN BARANG DAN JASA MELALUI PENINGKATAN PERAN ICT DALAM MEREDUKSI KORUPSI," $J$. Huk. Pembang., vol. 47, no. 4, pp. 477-496, 2017.

[5] ACCH, "TPK berdasarkan Jenis Perkara," Anti Corruption Clearing House, 2018. [Online]. Available: https://acch.kpk.go.id/id/statistik/tindak-pidana-korupsi/tpk-berdasarkan-jenisperkara. [Accessed: 01-Nov-2019].

[6] Arumsari, T. P., Iswahyudi, Mucharor, and A. P., "AUDIT ATAS PELAKSANAAN LELANG SECARA ELEKTRONIK DALAM PENGADAAN BARANG DAN JASA PEMERINTAH," http://www.bpkp.go.id, 2014. [Online]. Available: http://www.bpkp.go.id/investigasi/berita/read/13521/0/audit-atas-pelaksanaan-lelang-secaraelektronik-dalam-pengadaan-barang-dan-jasa-pemerintah.bpkp. [Accessed: 19-Sep-2019].

[7] R. Eadie, G. Heaney, and J. Carlisle, "Drivers and Barriers To Public Sector E-Procurement Within Northern Ireland ' S Construction Industry," Drivers Barriers To Public Sect. EProcurement Within North. Irel. 'S Constr. Ind., vol. 12, no. September 2006, pp. 103-120, 2007.

[8] L. A. Soetanto, "ANALISA KENDALA PELAKSANAAN E-PROCUREMENT DI KOTA SURABAYA," 2002.

[9] M. Nasrun Mohd Nawi, R. Deraman, J. Adewale Bamgbade, F. Zulhumadi, and S. Riazi Mehdi Riazi, "E-Procurement in Malaysian Construction Industry: Benefits and Challenges in Implementation,” Int. J. Supply Chain Manag., vol. 6, no. 1, pp. 209-213, 2017.

[10] M. M. Yusof, J. Kuljis, A. Papazafeiropoulou, and L. K. Stergioulas, "An evaluation framework for Health Information Systems: human, organization and technology-fit factors (HOT-fit)," Int. J. Med. Inform., vol. 77, no. 6, pp. 386-398, 2008.

[11] M. M. Yusof, R. J. Paul, and L. Stergioulas, "Health information systems evaluation: a focus on clinical decision supports system.," Stud. Health Technol. Inform., vol. 116, pp. 855-60, 2005.

[12] L. M. Erlirianto, A. H. N. Ali, and A. Herdiyanti, "The Implementation of the Human, Organization, and Technology-Fit (HOT-Fit) Framework to Evaluate the Electronic Medical Record (EMR) System in a Hospital," Procedia Comput. Sci., vol. 72, pp. 580-587, 2015.

[13] R. Kodarisman and E. Nugroho, "Evaluasi Penerapan Sistem Informasi Manajemen Kepegawaian ( SIMPEG ) di Pemerintah Kota Bogor," Jnteti, vol. 2, no. 2, pp. 24-32, 2013.

[14] D. Krisbiantoro, M. Suyanto, and E. Taufiqluthfi, "Evaluasi Keberhasilan Implementasi Sistem Informasi dengan Pendekatan HOT FIT Model ( Studi Kasus : Perpustakaan STMIK AMIKOM Purwokerto )," Konf. Nas. Sist. Inform., p. 6, 2015.

[15] M. M. Yusof, "A case study evaluation of a Critical Care Information System adoption using the socio-technical and fit approach," Int. J. Med. Inform., vol. 84, no. 7, pp. 486-499, 2015.

[16] M. M. Yusof, R. J. Paul, and L. K. Stergioulas, "Towards a Framework for Health Information Systems Evaluation," Proc. 39th Hawaii Int. Conf. Syst. Sci. - 2006, vol. 00, no. C, pp. 1-10, 2006. 